\title{
腎細胞癌の術後転移に関する臨床拈よび病理組織学的検討
}

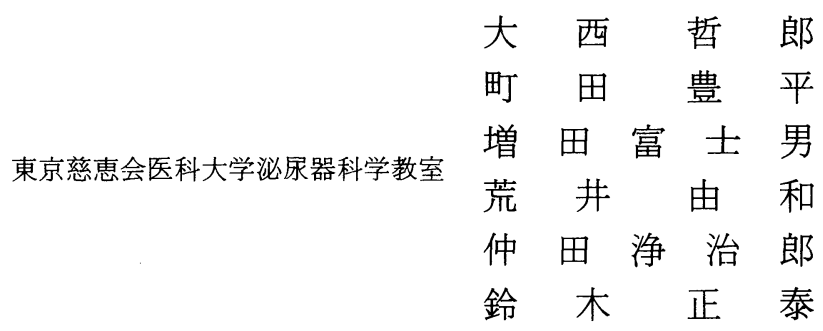

\section{CLINICAL AND PATHOLOGICAL STUDY ON VARIOUS METASTASES SECONDARY TO NEPHRECTED RENAL CELL CARCINOMA}

\author{
Tetsuro Onishi, Toyohei Machida, Fujio Masuda, Yoshikazu Arai, \\ Jojiro Nakada and Masayasu Suzuki \\ Department of Urology, The Jikei University School of Medicine \\ (Director: Prof. T. Machida)
}

Renal cell carcinoma is one of the most malignant neoplasms in the urological field. Most of them die as a result of metastases in clinical course. And this has been true in our experience, both for patients receiving chemotherapy and for those treated by nephrectomy. We present here the difference between cases without metastases over five years (28 cases, group I) and cases with metastase (33 cases, group II), with special reference to the clinical and pathological characteristics of patients with metastases secondary to nephrectomy.

There was no relationship between group I and group II concerning with site, mean age, period from the onset of symptoms and the first symptoms. The rapidity of metastasis seemed to vary with the site of metastasis: The median interval to first lung metastases after nephrectomy was one year and a month, hepatic metastases one year and two months, osseous metastases one year and three months, brain metastases one year and two months and lymph node metastases three years and five months.

The mean weight of nephrected tumor for group I was $396 \mathrm{gm}$ and that for group II was $571 \mathrm{gm}$. The mean diameter of the tumor for group I was $5.9 \mathrm{~cm}$ and that for group II was $7.4 \mathrm{~cm}$, but there was no significant difference between group I and group II.

There was no significant relationship between group I and group II concerning with preoperative laboratory findings, i.e., LDH, GOT, GPT, $\gamma$-GTP, Al-P, Ca, $\alpha_{2}$-globulin, E.S.R. and CRP.

A large percentage of group I patients were diagnosed low stage clinically, and low grade pathologically, compared with group II patients. And even in the low staged patients, most of group II patients were high graded. Therefore, histological grade was a critical factor of metastases concerning with postoperative renal cell carcinoma.

要旨：1957年 1 月より，1977年12月までの 21 年間に腎摘除術を施行した腎細胞癌のらち， stage 3 以下の 138 症例について, 手術後 5 年以上経て遠隔転移を認めない 28 例 (第 I 群) と, 術後転移を認めた 33 例(第 II 群)の 2 群間で, 臨床的および病理組織学的特徵について比較検討した. その結果, 罹患年㱓, 性別, 患側, 発症より来院までの期間および初発症状について，2 群間で差はなかった。また，体重減少，貧 血, Al-P 上昇例は, 第 I 群に比較して, 第 II 群にその陽性例が多くみられたが，統計的解析では差が認 められなかった，術後転移時期として，肺，肝，脳，骨，リンパ節の順に長くなる傾向であった．摘出 標本の大きさに関して，第 II 群が第 I 群に比較して，腎重量は重く，腫瘍径も長い傾向であったが有意 
差はみられなかった。

第 I 群では，第 II 群に比して， low grade, low stage が多く認められた。さらに，第 I 群の low stage

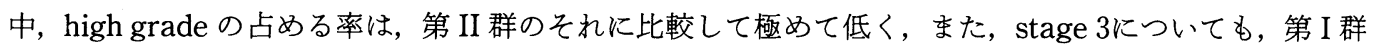
はすべて low grade であるのに対し, 第 II 群は, high grade が大半を占めた.つまり, 腎細胞癌の術後 転移に関して, stage 4を除くすべての stage にわたって grade が重要な因子と考えられた。

\section{緒 言}

腎細胞癌は, 尿路性器腫瘍のうちで最も予後の悪い ものの 1 つである，その大きな原因として，早期発見 が困難なこと，転移の様式が多様で，かつ不規則であ るため手術後でも，他の悪性腫瘍同様転移を来し易い ことなどがあげられる。そこで, 腎細胞癌の遠隔転移 に関し, 腎摘後 5 年以上転移再発を認めない症例と, 腎摘後転移をみた症例を比較し,臨床的病態を検討し， 特に腎摘後転移を生じた症例の臨木的および病理学的 特徵について検討する.

\section{対象}

この検討の対象となった症例は1957年 1 月より， 1977年12月までの 21 年間に慈恵医大泌尿器科拉よび関 連病院に打いて治療し, 病理組織学的に腎細胞癌々診 断された 138 症例で, これらのらち, 腎摘後 5 年以上経 て遠隔転移の認められない症例28例 (第 I 群), 腎摘後 転移症例33例（第 II 群）である。

\section{臨床および病理組織学的検討}

1）罹患年路, 性別, 患側扣よび発症より来院までの 期間について（表 1 ).

術後 5 年以上転移をみない症例群 (第 I 群)の年齢分 布では, 28歳から70歳, 平均54.3歳であった。性別で は, 男子16例, 女子12例 $(1.3: 1)$ で, 患側は, 右側 14例，左側14例と左右差はなかった。症状発現より来 院までの期間は, 最短 1 日, 最長 5 年, 平均 9 カ月で あった。

一方, 転移をみた症例群 (第 II 群)の年齢分布では,

表 1 罹患年齢, 性別, 患側拉よび発症より来院まで の期間

\begin{tabular}{|c|c|c|}
\hline 項 目 & 第 I 群 $(n=28)$ & 第 II 群 $(n=33)$ \\
\hline $\begin{array}{l}\text { 罹 患 年 齡 } \\
\text { (平 均) }\end{array}$ & $\begin{array}{l}28 \sim 70 \\
(54.3 \text { 藏 })\end{array}$ & $\begin{array}{l}31 \sim 76 \\
(53.7 \text { 歳 })\end{array}$ \\
\hline 性別(男：女) & $1.3: 1$ & $2: 1$ \\
\hline 患側(左：右） & $1: 1$ & $1: 1.5$ \\
\hline $\begin{array}{l}\text { 発症より来院 } \\
\text { までの期間(平均) }\end{array}$ & $\begin{array}{c}\text { 1日〜5年 } \\
(9 \text { カ月21日 })\end{array}$ & $\begin{array}{c}\text { 1日〜2年3 月 } \\
\text { ( } 5 \text { カ月 } 9 \text { 日) }\end{array}$ \\
\hline
\end{tabular}

31歳から76歳, 平均53.7歳であった。性別では, 男子 22例, 女子11例 $(2: 1)$ で, 患側は, 右側13例, 左側 20例（1:1.5）であった。症状発現より来院までの期 間は, 最短 1 日, 最長 2 年 3 力月, 平均 5 力月であっ た。

以上の結果， 2 群間で平均罹患年齢，性別，患側に 差がなかった。また症状発現より来院までの期間をみ ると，第 I 群が第 II 群より長い傾向であった。

2) 初発症状（表 2)

術後 5 年以上転移をみない症例群 (第 I 群)は, 肉眼 的血尿 24 例 (85.7\%), 腫瘤触知 5 例 (17.9\%) 打よび 腎部痛 6 例 $(21.4 \%)$ などの尿路症状を呈した例が大 半を占めた，尿路外症状として，熱発を 1 例 (3.6\%) に認めたのみであった。

転移をみた（第 II）群で, 肉眼的血尿は, 27例 (81.8\%), 腫瘤触知は 5 例 $(15.2 \%)$ 抢よび腎部痛は 6 例 (18.2\%) であった。食思不振, 体重減少, 熱発 などの尿路外症状はそれぞれ，1例ずつ(3.0\%)であっ た.

以上の結果から, 初発症状は第 I 群と第 II 群間に差 は認められなかった。

3）入院時臨床所見（表 3 ）

入院時徵候として, 体重減少, 貧血 (Hb值が $12.0 \mathrm{~g} /$ $\mathrm{dl}$ 以下), 赤沈六進 ( 1 時間值が $30 \mathrm{~mm}$ 以上の充進例), 熱発 (腋窝温にて $37.0^{\circ} \mathrm{C}$ 以上を記録した例) について, 第 I 群と第 II 群を比較検討した。その結果, 第 I 群で

表 2 初発症状

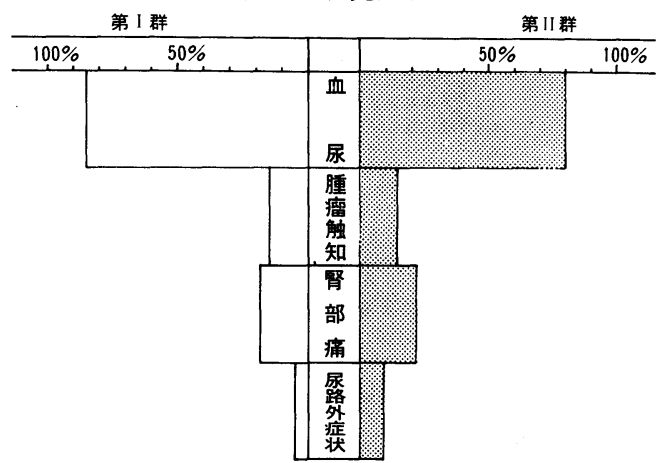


表 3 入院時所見

\begin{tabular}{|c|c|c|c|}
\hline & 第 1 群 $(n=28)$ & 第 II 群 $(n=33)$ \\
\hline \multirow{4}{*}{$\begin{array}{l}\text { 入 } \\
\text { 院 } \\
\text { 時 } \\
\text { 徵 } \\
\text { (管) }\end{array}$} & 体重隇少 & 7 & $\begin{array}{l}25.8 \\
(※ P<0.05)\end{array}$ \\
\hline & 筫 血 & 4.8 & 19.4 \\
\hline & 血沈穴進 & 42.9 & 58.1 \\
\hline & 熱 発 & 33.3 & 29.0 \\
\hline \multirow{7}{*}{ 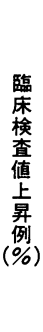 } & LDH & $\sim$ & 9.7 \\
\hline & $\begin{array}{l}\text { GOT } \\
\text { GPT }\end{array}$ & 9.5 & - \\
\hline & $\gamma$-GTP & $\sim$ & 9.7 \\
\hline & $A 1-P$ & $\sim$ & $\Gamma$ \\
\hline & $\mathrm{Ca}$ & 5.0 & 6.5 \\
\hline & $\alpha_{2}-g \mid$ & 63.2 & 60.0 \\
\hline & CRP & 11.1 & 44.0 \\
\hline
\end{tabular}

表 4 肺肝転移時期とその数

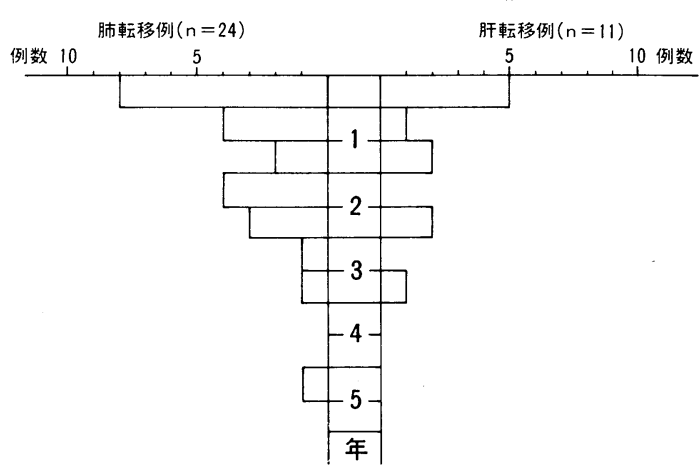

は，体重减少は認められず，貧血は 1 例 $(4.8 \%)$, 赤 沈穴進は 9 例 $(42.9 \%)$, 発熱は 7 例 $(33.3 \%)$, 第 II 群では，それぞれ，8例 (25.8\%)，6 例 (19.4\%), 18例 (58.1\%), 9 例 (29.0\%) であった.

また, 臨床検査值では, LDH, GOT および GPT, $\boldsymbol{\gamma}$ GTP, Al-P, Ca, $\alpha_{2}$-globulin, CRP について検討した. その結果, 第 I 群での異常値発現率は, LDH ( $0 \%)$, GOT および GPT 2 例 (9.5\%), $\gamma$-GTP ( $0 \%), A l-$ $\mathrm{P}(0 \%), \mathrm{Ca} 1$ 例 $(5.0 \%), \alpha_{2}$-globulin 12 例(63.2\%), CRP 2 例 (11.1\%)，第 II 群では，それぞれ，3 例 (9.7\%)， $0 \% ， 3$ 例 $(9.7 \%), 0 \%, 2$ 例 $(6.5 \%)$, 15例 (60.0\%)，11例 (44.0\%) に上昇例が認められた。

以上の結果をまとめると, 入院時徵候陽性例, 臨床 検査值上昇例とも, 第 I 群より第 II 群がやや多くみら れる結果であったが，体重減少例 $(\mathrm{p}<0.05)$ を除いて 統計的に有意差はなかった。
表 5 骨, リンパ節転移時期とその数

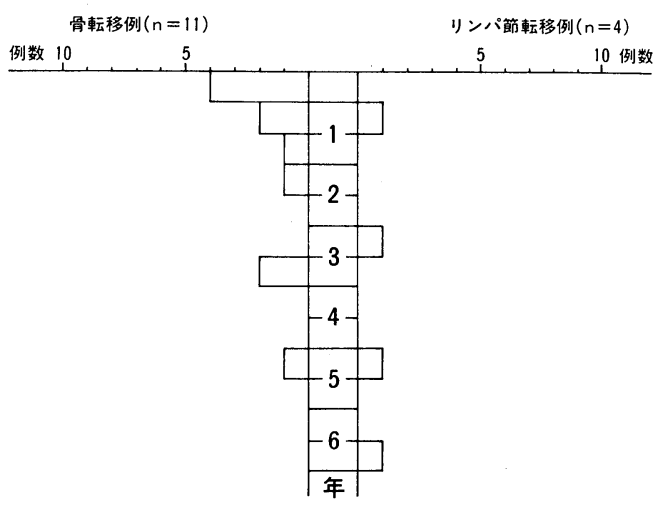

表 6 脳転移時期とその数 $(n=11)$

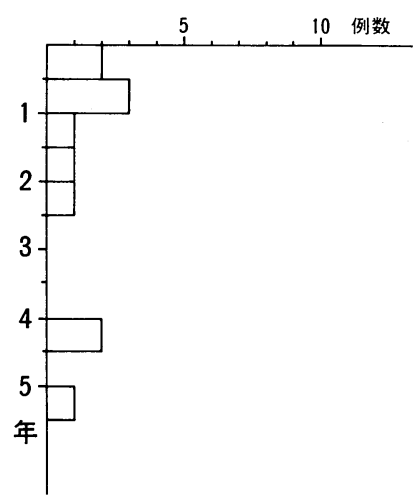

\section{4）遠隔転移（表 4 6)}

術後転移例 (第 II 群) 33例の転移藏器と転移発生产 での期間を調査した。肺転移を生じた例は24例 (72.3\%)で，その転移を生じるまでの期間は， 6 力月 以内が 8 例 $(29.2 \%), 6$ 力月から 1 年をでが 4 例 (16.7\%)， 1 年から 2 年末でが 6 例( $15.0 \%), 2$ 年か ら 3 年までが 4 例 $(16.7 \%), 3$ 年から 4 年までが 1 例 $(4.2 \%), 4$ 年から 5 年までが 1 例 (4.2\%) であり, 肺転移を生じるまでのメジアン(the median interval) は 1 年 1 カ月間であった。

肝転移を生じた11例（33.3\%）の転移を生じるまで の期間は， 6 力月以内が 5 例 (45.5\%)， 6 力月から 1 年までが 1 例 $(9.1 \%), 1$ 年から 2 年までが 2 例 $(18.2 \%), 3$ 年から 4 年までが 1 例 (9.1\%) であり, 肝転移までのメジアンは 1 年 2 カ月であった。

骨転移を生じた11例（33.3\%）の転移を生じるまで の期間は, 6 カ月以内が 4 例 $(36.4 \%), 6$ カ月から 1 年までが 2 例 $(18.2 \%), 1$ 年から 2 年までが 2 例 
$(18.2 \%), 3$ 年から 4 年までが 2 例(18.2\%), 4 年か ら 5 年までが 1 例 (9.1\%) であり，骨転移までのメジ アンは 1 年 3 カ月であった。 また，その転移部位とし ては, 大腿骨 6 例 $(35.3 \%)$, 腰椎骨 4 例 $(23.5 \%)$, 坐骨 2 例 (11.8\%), 以下，肩甲骨，上腕骨，胸椎骨， 仙骨がそれぞれ 1 例ずつ（5.9\%）であった。

リンパ節転移は 4 例（12.1\%）であるが，その転移 が発見されるまでの期間は，6力月以内がなく，6力 月から 1 年末でが 1 例 (25.0\%), 2 年から 3 年末でが 1 例 $(25.0 \%), 4$ 年から 5 年末でが 1 例 $(25.0 \%)$, 6 年から 7 年までが 1 例 $(25.0 \%)$ であり，リンパ節 転移までのメジアンは 3 年 5 カ月であった。

脳転移を生じた11例（33.3\%）の転移を生じるまで の期間は， 6 力月以内が 2 例 $(18.2 \%), 6$ 力月から 1 年までが 3 例 $(27.3 \%), 1$ 年から 2 年までが 2 例 $(18.2 \%), 2$ 年から 3 年までが 1 例 $(9.1 \%), 4$ 年か 55 年までが 2 例( $18.2 \%), 5$ 年から 6 年までが 1 例 (9.1\%) であり，脳転移までのメジアンは 1 年 2 カ月 であった。

その他，皮下に 1 例 $(3.0 \%), 1$ 年 5 力月で転移を 生じた症例があった。

以上の結果, 腎摘後臨床経過中に遠隔転移を生じた 33例のうち, 肺, 肝, 脳, 骨, リンパ節の順に転移が 多くみられた。 また，転移を生じるまでのメジアンも， 肺で 1 年 1 力月, 肝で 1 年 2 力月, 脳で 1 年 2 力月, 骨で 1 年 3 カ月, リンパ節で 3 年 5 カ月の順であった.

5) 摘出腫瘍（腎）の大きさ（表 7 ）

第 I 群の最小重量は $125 \mathrm{~g}$, 最大重量は $1,020 \mathrm{~g}$, 平均 $396 \mathrm{~g}$ （SD：241g）であった。 また, 腫瘍の短径は2.5 $\mathrm{cm}$, 長径は $10.5 \mathrm{~cm}$, 平均 $5.9 \mathrm{~cm}(\mathrm{SD}: 2.1 \mathrm{~cm})$ であっ た.

第 II 群の最小重量は $198 \mathrm{~g}$, 最大重量は $1,990 \mathrm{~g}$, 平均 $571 \mathrm{~g}(\mathrm{SD}: 357 \mathrm{~g})$ であった。 また腫瘍の短径は $2.0 \mathrm{~cm}$, 長径は $18.0 \mathrm{~cm}$, 平均 $7.4 \mathrm{~cm}(\mathrm{SD}: 3.1 \mathrm{~cm})$ であった。

この結果, 摘出腎標本重量, および腫瘍径ともに,

第 I 群が第 II 群に比較して，やや小さい傾向であった が，両者間に有意差はなかった。

6) 組織学的悪性度（表 8)

核異型を中心に, 構造異型も考慮して腎細胞癌の病 理組織学的悪性度分類を行った。

第 I 群では, grade I が11例 (39.3\%), grade II が 16例 $(57.1 \%)$, grade III が 1 例 (3.6\%), grade IV は認められなかった。

第 II 群では, grade I が 3 例 (9.1\%), grade II が
表 7 摘出標本重量と腫瘍径

\begin{tabular}{c|c|c}
\hline & 第 $\mathrm{I}$ 群 $(\mathrm{n}=28)$ & 第 II 群 $(n=33)$ \\
\hline $\begin{array}{c}\text { 最大重量〜最小重量 } \\
\begin{array}{c}\text { (平均重量) } \\
\mathrm{g}\end{array}\end{array}$ & $\begin{array}{c}125 \sim 1,020 \\
(396)\end{array}$ & $\begin{array}{c}198 \sim 1,990 \\
(571)\end{array}$ \\
\hline 短 $_{\begin{array}{c}\text { 径〜長 } \\
(\text { 均 })\end{array}}$ 径 & $\begin{array}{c}2.5 \sim 10.5 \\
(5.9)\end{array}$ & $\begin{array}{c}2.0 \sim 18.0 \\
(7.4)\end{array}$ \\
\hline
\end{tabular}

表 8 組織学的悪性度分布

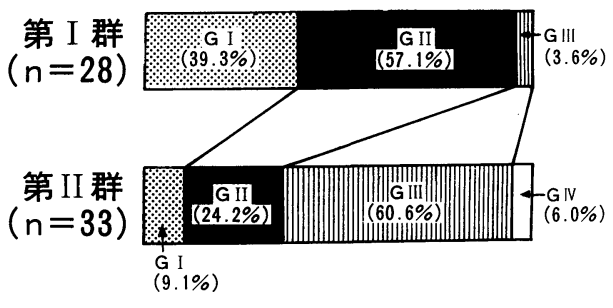

表 9 術前臨床病期

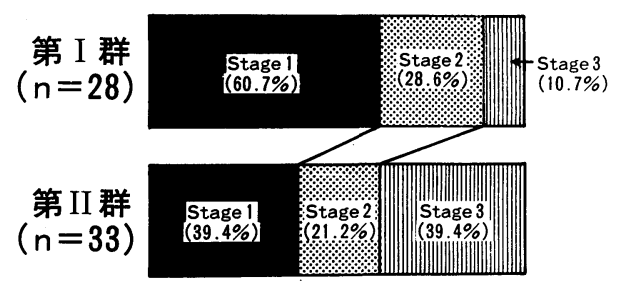

8 例 (24.2\%), grade III が20例 (60.6\%), grace IV が 2 例(6.0\%)であった。すなわち, 第 I 群では, low grade (grade I および grade II) が28例 中27例 (96.4\%) と大半を占めているのに対し, 第 II 群では逆 に, high grade (grade III 拈よび grade IV) が33例 中22例 (66.6\%) と大半を占める結果であった。

7) 手術時臨床病期（表 9 )

第 I 群では, stage 1 落17例 (60.7\%), stage 2 が 8 例 (28.6\%), stage 3 が 3 例 (10.7\%) であった。一方,

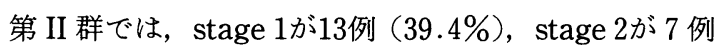
(21.2\%), stage 3が13例（39.4\%）であった.

すなわち, 第 I 群では, 28例中 25 例 (89.3\%) と大半 が low stage (stage 1㧊よび stage 2) で占められてい るのに対し，第 II 群では逆に，33例中13例 (39.4\%) が high stage (stage 3) であり, high stage の率の増 加がタられた。

8）各臨床病期に招ける組織学的悪性度分布（表10）

第I群のらち, stage 1では, grade Iが 8 例 (40.1\%), grade II が 9 例 (52.9\%) であった. stage

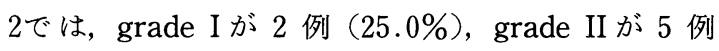


表10 各臨床病期に打ける組織学的悪性度分布

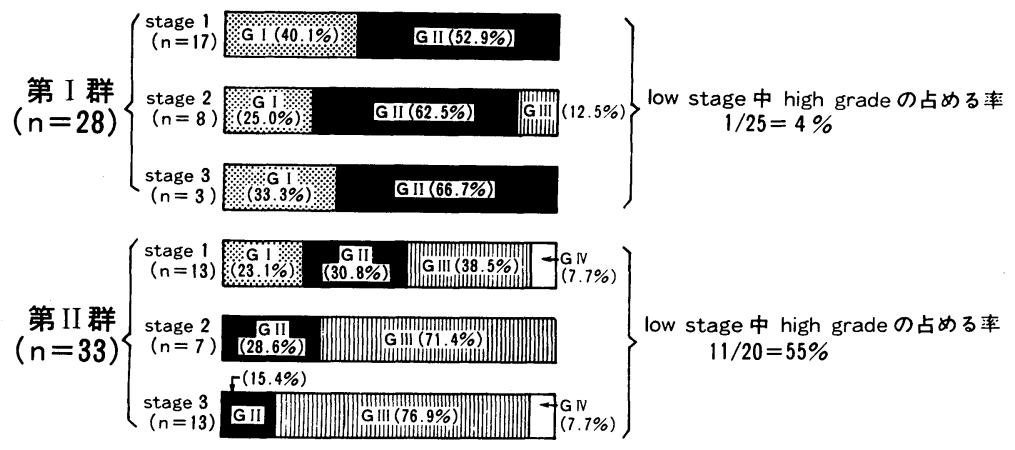

(62.5\%), grade IIIが 1 例 (12.5\%) であった. stage 3 では, grade Iが 1 例 $(33.3 \%)$, grade II が 2 例 (66.7\%) であった.

同様に，第 II 群のうち, stage 1では, grade I が 2 例 $(23.1 \%)$, grade II が 4 例 $(30.8 \%)$, grade III が 5 例 $(38.5 \%)$, grade IV が 1 例 $(7.7 \%$ ) であった. stage 2では, grade II が 2 例 (28.6\%), grade III が 5 例 $(71.4 \%)$ であった. stage 3では, grade II が 2 例 (15.4\%), grade III が10例 $(76.9 \%)$, grade IV が 1 例 $(7.7 \%)$ であった.

以上の結果, 第 I 群では, low stage 中, high grade の占める率は，25例中 1 例 (4\%) と, 大半が low grade であった.逆に, 第 II 群では, low grade 中, high grade の占める率が20例中11例 $(55.0 \%$ ） と，第 I 群のそれ に比較して, high gradeの占める率が高く, high stage (stage 3）についても同様の傾向であった.

\section{考 案}

近年, 悪性腫瘍の治療の進歩には目覚しいものがあ るが，いかなる悪性腫瘍においても，予後を向上させ る第 1 の条件は, 今も昔も早期発見早期治療であるこ とは変らない。

腎細胞癌は, 多彩な臨床症状をとることが指摘され て括り，泌尿器科に受診時すでに遠隔転移を認める例 も多いばかりでなく，術後転移や再発を来し易く，予 後の良くない腫瘍とされている.

このため, 予後に影響する臨床的諸因を，腎摘後 5 年以上転移再発を認めない例 (第 I 群) と, 腎摘後転移 例（第 II 群）との間で比較検討した。

症状発現より来院までの期間をみると, 土田ら"の 報告では，平均して18力月間で来院して扣り，特に 1 年以内に来院した例に予後が良い傾向であると述べて 扣り, Bennigton ら同様の報告を行っている。しか
し，我々の結果では，術後転移を来した第 II 群の来院 までの期間が 5 力月間と，第 I 群の 9 力月間より短か く, 必ずしも症状発現から来院までの期間が短かい汪 ど転移発現が遅いといら傾向は認められなかった（表 1 ).

また様々の初発症状についてみても, 第 I 群と第 II 群間で，尿路症状および尿路外症状とも頻度に有意差 はなく(表 2 ), 初発症状と予後には直接関係がないと 考えられた。

入院時検査所見では, 体重減少, 赤沈の元進および 原因不明の熱発などの徵候は, 腎細胞癌の診断の際, 特異的ではないが癌進行の徴候として，しばしば重要 視される3). しかし，我々の検討では，第 I 群と第 II 群 の間にほとんど有意差はみられなかった。

熱発に関しては，特に腫瘍がかなり進行したり，あ るいは腫瘍の生物学的活性が高まっている場合生じる と報告されている3). しかし，我々の症例の比較では， 術後転移との関連は少なかった。

また，臨床検査のうち，GOT および GPT, $\gamma$-GTP, Al-P などの肝機能検査の異常は, 腎細胞癌の予後を左 右するといら報告があり"4), さらにUtz), Warren ら)は, 腎摘後肝機能異常を呈する症例は予後も悪く, 転移を生じている可能性があると報告している。しか し, 我々の結果では, LDH, GOT および GPT, $\gamma$-GTP, Al-P のいずれの上昇率についても第 I 群と第 II 群間 で差は認められず，肝機能障害を示す検査値は，必ず しも転移と関連があるとはいえないと思われる。すた， 高 Ca 血症, $\alpha_{2}$-globulinの高値例に関しても 2 群間に 差がみられなかった。 $\alpha_{2}$-globulinの上昇は, 腎細胞癌 に沶ける血清蛋白異常の特徴とする者もいる ${ }^{8)}$ が，必 ずしも腎細胞癌の浸潤度，掞よび転移とは関係がない と考えられる。 
細菌感染症に鋭敏に反応する CRP は，腎細胞癌に おいても陽性化することは知られている899)。乙か子， 腎摘後 CRP の陰性化が予後良好の因子となりらるこ とを強調した報告も認められる8). 我々は，腎摘後の CRP の陰性化について全例に検討していないが，術 前, 第 II 群が第 I 群に比較して陽性率が高く，腎細胞 癌の術後転移と, CRP の陽性化は相関する傾向にある と考学られた。

腎細胞癌の遠隔転移は, 血行性, リンパ行性および 直接浸潤によって生じ，剖検時の検討では，肺，リン 八節，肝，骨，副腎，対側腎，脳，心，脾，小腸，皮 膚, 横隔膜, その他への広がりがみられる ${ }^{10)}$. 臨床経過 中，術後転移を生じた例を検索した結果，遠隔転移部 位と腎摘後転移を生じるまでの期間をまとめたのが表 $4,5,6$ である。

術後転移例と剖検時の結果を比較して，大きく異な る点は，リンパ節転移例が術後転移に少ないことであ る。また，肺，肝，骨，脳は術後 2 年以内に転移を生 じているのに比較して，リンパ節転移例は，術後転移 を生じるまでの期間が 3 年 5 カ月と最も長く，これは 臨床的にリンパ節転移の証明のむずかしさを示してい る.

以前より，リンパ節転移の診断に関しては，かなり 進展してはじめて発見される傾向にあるが，今後は CT scan などの導入によって，比較的早期に，かつ正 確になされるようになると思われる。

腎摘後転移を生じた転移臓器総数61のうち, 腎摘後 5 年以内の転移藏器総数は59（96.7\%） と大半を占め て抢り，このことから，腎摘後転移再発は汪とんど 5 年以内に生じるとい兄よう。しかし，一方，腎細胞癌 のなかには 10 年, 15 年経ても転移再発を生じる例 （slow type）も報告されている11).こうした転移の病 態からみると, 腎細胞癌の術後の経過観察には, 術後 2 年間は臨床医の厳重な監視下に拈き，少くとも 3 力 月に 1 回は, 胸部 X線撮影を施行し， 6 力月に 1 回は 後腹膜 CT scan 検査, 肝拉よび骨シンチが必要で, 3 年目以降は 5 年まで上記の検査を $6 \sim 12$ カ月に 1 回施 行して観察する必要があると思われる.

摘出標本の重量と予後との関係については, 松田 $ら^{12)}$ は $500 \mathrm{~g}$, 佐藤ら ${ }^{13)}$ は $400 \mathrm{~g}$ 以上の場合には予後が悪 いとしている.我々の結果も, 第 II 群の平均重量は500 $\mathrm{g}$ をこえて扣り，第I群のそれ(396g) に比較して重い 傾向を示していたが，統計学的には有意差はなかった (表 7 )。一般的には，摘出腎重量の増大に伴って手術
的操作が困難となり, 根治的腎摘除がおろそかになり がちであることも事実で, 摘出腎が約 $400 \mathrm{~g}$ (第 I 群の平 均重量）をこえる際は，術後経過観察にも十分な注意 と同時に術後療法を考慮すべきであろう。

また，腫湯径と予後についてもA Arner ${ }^{14)} ら は ， 7 \mathrm{~cm}$ 以下とそれ以上の群で予後を比較し， 5 年生存率に差 がみられたと報告しているが，臨床的には重量と同様 な意味をもつものと思われる（表 7).

腎細胞癌の組織学的所見は，その予後を左右する最 も重要な因子として最近注目されて扔り ${ }^{11)}$, 我々もす でに報告したが ${ }^{15)}$ ，今回は，転移症例と非転移症例を中 心に検討したが，組織学的悪性度と易転移性との関係 が認められた(表 8 )。すなわち, 第 II 群は第 I 群に比 較して, high grade (grad III 拈よび grade IV) の占 める割り合いが高く, 結局, 腎細胞癌の転移は, grade の高くなる泀ど転移が生じやすい傾向がみられた。

さらに, 臨床病期は当然腎細胞癌の予後に重要な影 響を与える因子であるが，第 II 群は第 I 群に比較し て, high stage の占める割り合いが多く(表 9 ), 特に stage 3 症例の初回時の根治的治療，打よび術後療法 の必要性を感じる。

各臨床病期に拈ける組織学的悪性度分布をみると， 第 I 群では, low stage が多くを占めることは前述した が， low stage のうち， high grade の占める率が第 II 群のそれに比較して著明に低い結果であった（表10）. また， stage 3，16例中13例（81.3\%）が，腎摘後転移 を生じており，他の stage に比較して最も転移を生じ やすい結果であったが, 第 I 群の stage 3はすべて low grade であり, 一方, 第 II 群の stage 3 は $84.6 \%$ high gradeで占められて打り，腎摘後転移を最も生じやす い stage 3 といえども，low stage 同様，組織学的悪性 度が転移の生じやすさに関し，重要な役割りをはたし ていることを示唆するものと考兄られる。

以上の予後に関する諸因子の検討からみても，腎細 胞癌の病態, 特にその転移様式の多様性と複雑性が浮 彫された。結果，予後に大きな影響を与えるのは，腫 瘍自体の進展度と，その組織型といら実型的な結論と なったが，それだけに早期診断の対策が急務の問題と 思われる。

\section{結語}

1957年 1 月より，1977年 12 月までの 21 年間に慈恵医 大招よび関連病院に执いて治療した腎細胞癌 138 症例 のらち, 腎摘後 5 年以上転移再発を認めない28例（第 I 群)，扣よび腎摘後転移例33例（第 II 群）を対象に, 
罹患年齢，性別，患側，発症より来院までの期間，初 発症状, 入院時臨床検查所見, 転移部位とその時期, 摘出標本重量と腫瘍径, 病理組織学的悪性度および病 期に関して 2 群を比較検討した。

1. 平均䍜患年齢, 性別, 患側, 発症より来院までの 期間，および初発症状に関して 2 群間に有意差が認め られなかった。また，体重減少，貧血の有無， Al-P 上 昇等臨床検查值的異常は, 術後転移をみた第 II 群に多 く認められた。しかし，体重減少を除いて統計的解析 では有意差はなかった。

2. 術後転移部位として, 肺，肝，脳，骨，リンパ節 の順に多く認められ，転移を生じるまでの期間もこの 順に長くなる傾向であった。

3. 摘出標本の大きさに関しては,大きい活ど予後が 悪い傾向がみられたが，有意差はなかった。

4. 第 I 群では, 病理組織学的に low grade が多く, 一方, 第 II 群では, high grade が多く占めた。また, 第 I 群では, low stage が多く, 第 II 群では, high stage が多くを占めた。ささら，第I 群の low stage 中, high grade の占める率は, 第 II 群のそれに比較して極めて 低く, stage 3についても，第I群はすべて low grade であるのに対し, 第 II 群では, high grade が大半を占 めた. 以上, 予後に最も大きな影響を与える因子とし ては，腫瘍自体の進行度と細胞異型度であることが判 明した。

本論文の要旨は第21回日本癌治療学会総会において発表 した。なお本研究の一部は厚生省腎がん研究助成 (57-16) によって行われた。

\section{文献}

1）土田正義, 菅原博厚：腎腫瘍の予後に関する研究。 日泌尿会誌，59，847-856，1968.

2) Bennigton, J.L. and Kradjian, R.M.: Renal Carcinoma. p. 34-39, Saunders, Philadlphia, 1967.

3）阿曾佳郎, 田島 嵉; 不明熱. Medicina，19,
2472-2472, 1982

4）増田富士男, 佐々木忠正, 高橋宣久, 荒井曲和, 南 武：腎細胞癌の尿路外症状。泌尿紀要, 21 , 595-603, 1975 .

5）增田富士男, 佐々木忠正, 渡辺秀雄, 荒井由和, 町 田豊平：腎細胞癌にみられる肝機能障害. 日泌尿 会誌，22，91-96, 1976.

6) Utz, D.C., Warren, M.M., Gregg, J.A., Ludwig, J. and Kelalis, P.P.: Reversible hepatic dysfunction associated with hypernephroma. Mayo Cli. Proc., 45, 161-169, 1970.

7) Warren, M.M., Kelalis, P.P. and Utz, D.C. : The changing concept of hypernephroma. J. Urol., 104, 376-379, 1970.

8）里見佳昭：腎癌の予後に関する臨床的研究一特に 生体側の因子を中心に一。日泌尿会誌，64, 195-216, 1973.

9）都田慶一, 渡辺 泱, 三品輝男, 荒木博孝, 藤原光 文, 小林徳朗：過去11年間に括ける腎細胞癌 (44 例)の統計的観察. 西日泌尿会誌, 40, 53-64, 1978.

10) Bennigton, J.L. and Beckwith, J.B.: Tumors of the kidney, renal pelvis, and ureter. A.F.I.P., p. 168-177, Washington, D.C., 1975.

11）里見佳昭, 高井修道, 近藤猪一郎, 岩崎孝史, 吉邑 貞夫, 福島修司, 古烟哲彦, 石塚栄一：腎細胞癌の stage 及び grade と予後. 日泌尿会誌, 72, 278-287, 1981.

12）松田 稔, 長船匡男, 古武敏彦, 園田孝男：腎細胞 癌の臨床的研究. 日泌尿会誌, 67, 635-646, 1976.

13）佐藤昭太郎, 渡辺悌三：腎腫場の臨床的観察, 特に 臨床成績と予後について。日泌尿会誌，61, 231-242, 1970.

14) Arner, O., Blanck, C. and von Schreeb, T.: Renal adenocarcinoma, Morphograding of malignancy prognosis, A study of 197 cases. Acta Chir. Scand. Suppl., 346, 1-15, 1965.

15）大西哲郎, 町田豊平, 増田富士男：腎細胞癌の病理 組織学的検討. 第 2 報。病理組織像と予後。日泌尿 会誌, 74, 2097-2106, 1983.

（1983年11月1日受付） 